\title{
REVISTA MORINGA - ARTES DO ESPETÁCULO
}

\section{ORIENTAÇÃO AOS COLABORADORES}

As colaborações devem ser enviadas para o e-mail moringa.ufpb@gmail.com aos cuidados dos editores. O corpo do e-mail deve conter todos os dados de contato do autor (nome completo, endereço, telefone). Aos artigos aprovados para publicação, serão mantidos os direitos de autor (copyrights), não havendo custos de processamento e nenhuma taxa de publicação.

\section{Normas para publicação}

Os textos devem ser inéditos, em arquivo Word, com o mínimo de dez e máximo de dezesseis páginas. Textos menores ou mais longos serão aceitos somente com autorização do editor ou aprovação do Conselho Editorial. A formatação deve ser em espaço $1 \frac{1}{2}$ e letra Times New Roman 12, com o título em maiúscula e em negrito, seguido do nome e informações sobre o autor (titulação, área, instituição).

O resumo e o abstract devem estar na primeira página, abaixo das informações sobre o autor, apresentando uma perspectiva concisa do tema, da abordagem e das conclusões. Não devem exceder, cada um, 5 linhas ou 460 caracteres, em tamanho e tipo padrão já mencionados, seguidos de três palavras-chave / keywords.

As citações que tenham até três linhas devem vir no próprio corpo do texto, entre aspas, seguidas da referência entre parêntesis (sobrenome do autor em maiúscula, ano da publicação e página). Caso excedam esse número, devem ser formatadas em letra Times New Roman, tamanho 10, com recuo de parágrafo em 4,0 cm e espaçamento simples entre as linhas. Já as notas devem ser de rodapé, ou seja, ao fim da página em que se insere, contendo apenas informações indispensáveis e complementares. As referências bibliográficas devem vir por último, no final do texto, listando preferencialmente as obras citadas no correr do texto e seguindo as normas da ABNT.

Os autores serão informados da aceitação ou não de seu artigo. Em razão de um possível excesso de contribuições, os textos aprovados poderão ser publicados em edições posteriores, desde que com a concordância de seus autores.

Revista Moringa - Artes do Espetáculo

Departamento de Artes Cênicas - CCTA

Universidade Federal da Paraíba

Conjunto Humanístico - Bloco IV - Cidade Universitária

CEP 58059-900 João Pessoa - PB 